\title{
Minor psychiatric morbidity and labour turnover
}

\author{
RACHEL JENKINS
}

From the Institute of Psychiatry, Denmark Hill, London SE5 8AF, UK

ABSTRACT The relation of minor psychiatric morbidity with labour turnover is examined, using $\stackrel{\triangleright}{\stackrel{D}{\sim}}$ data from a study of young, predominantly middle class, white collar men and women. The results suggest that the presence of psychiatric symptomatology is at least as important as occupational attitudes in identifying individuals who would subsequently leave the organisation.

Over the past few decades, the extent of minor psychiatric morbidity in the general adult population has been charted in surveys of general practice, ${ }^{1}$ in community surveys, ${ }^{2}$ and in occupational surveys. ${ }^{34}$ Reported prevalence rates vary from population to population and with the screening method used. ${ }^{5}$ Nevertheless, most surveys agree on the broad range of $10-30 \%$. Such prevalence rates are clearly high and it is, therefore, important to assess how costly minor psychiatric morbidity is to the individual, not only in terms of distress but also in terms of the associated handicap.

The association of minor psychiatric problems with social dysfunction has been explored to some extent. ${ }^{6}$ There has, however, been a notable absence of research on the problems posed by minor psychiatric morbidity in occupational settings where people often spend more than half their waking hours. It is of practical importance both to industry and the occupational medical services to understand the effect of minor psychiatric morbidity on sickness absence, relations with colleagues, work performance, accidents, and labour turnover.

Labour turnover is costly to the employer in terms of wasted training resources and work experience and is potentially costly to the individual in terms of disrupted career pattern, attendant social disruption such as loss of colleagues, a break in income, insecurity for the family, and the risk of unemployment. This report examines the relation of minor psychiatric morbidity with labour turnover in a young, predominantly middle class white collar population of men and women.

\section{Method}

The data for this report are drawn from a study of the prevalence and outcome of minor psychiatric

Received 17 September 1984

Accepted 15 October 1984 morbidity, and its attendant illness behaviour, in $\frac{\mathbb{}}{3}$ male and female executive officers in the Civil Service. The design and methodology are described in ${ }_{\infty}^{N}$ detail elsewhere. ${ }^{4}$ Eligible respondents were $i$ selected from a computer listing of all executive ${ }_{\perp}^{\omega}$ officers in the Home Office, specifying sex, date ofo birth, tenure in post, and method of entry to the ${ }_{-}$ grade. The criteria of entry to the study were age $>$ between 20 and 35, tenure between one and 100 years, appointment to the Civil Service on the basis $\frac{1}{9}$ of performance in the open entrance examination, $\overrightarrow{-}$ and job location in London offices. The establish-o ment wrote to each executive officer indicating the. general purpose of the study ("an investigation into응 the health of professional men and woment) emphasising the confidential nature of the investigat-⿳亠二口犬 tion and asking for voluntary participation. Consent forms were then supplied to the investigator, and the $\stackrel{\mathbb{Q}}{\stackrel{Q}{2}}$ responders formed the study population. All $\overrightarrow{\vec{F}}$ responders were initially contacted by postal ques- $\frac{\hat{3}}{3}$ tionnaire and subsequently a proportion were interviewed.

Minor psychiatric morbidity was assessed by a two stage screening survey, using the general health $\frac{\mathbb{}}{3}$ questionnaire $^{7}$ as the screening test, administered to all respondents, to identify probable cases (GHQ positives) and probable non-cases (GHQ negatives). The clinical interview schedule ${ }^{8}$ was used as the reference test and was administered by a trained psychiatrist to all the identified GHQ positives and? to a random one in two sample of the GHQ nega- $\frac{D}{0}$ tives.

Demographic data on age, sex, marital status, $\stackrel{N}{\sim}$ number of children, tenure, and travel distance to work were also collected at the clinical interview.

Occupational attitudes were measured at the clini- $\omega$ cal interview, using comprehensive, validated scales $\stackrel{\sim}{2}$ to assess work involvement (the extent to which a person wants to be engaged in work in general, as opposed to the present job in particular), intrinsic 
job motivation (motivation towards personal achievement and task success), higher order need strength (motivation to paid work in general), perceived intrinsic job characteristics, job satisfaction, and job attachment ${ }^{9}$ (N Nicholson, R Payne, personal communication).

Social stress and supports were measured by a brief interview after the clinical interview covering the life domains of occupation, finance, housing, social life, marriage, and family. ${ }^{10}$

Domestic activities and responsibilities were assessed by a brief structured questionnaire administered by post, at the same time as the general health questionnaire, to all respondents. ${ }^{4}$

Sickness absence was measured for each respondent for the 12 months preceding the date of the clinical interview by extracting the relevant recorded data from the sickness absence files kept by the Home Office Establishment on every employee. Absence was recorded in terms of frequency (spells) and duration (days), both certified and uncertified. During the period of the study (1979-81) civil servants could take up to 10 uncertified days of absence in any period of 12 months. All spells of absence of three days or more needed certification by the general practitioner concerned. A civil servant may be referred to the medical advisory service of the Civil Service if his rate of sick leave seems to be excessive.

Labour turnover-One year and two years after the date of the first clinical interview the names of executive officers who had left the Home Office in the intervening period were supplied to the investigator.

The alcohol consumption of each individual was estimated for the seven days preceding the clinical interview by asking the interviewee to recall the quantity and frequency of the three broad classes of alcohol (beers, wines, and spirits) consumed in the preceding week. It was then possible to calculate the grams of absolute alcohol estimated to have been consumed in that week.

\section{Results}

RESPONSE RATE

Examination of the current computer listing of Home Office employees gave the names of 230 male and 167 female executive officers who fulfilled the criteria for entry into the study. Of these, 183 men and 138 women agreed to participate in the study and completed the general health questionnaire, giving a response rate, for both sexes combined, of $81 \%$.

Table 1 Comparison of the characteristics of stayers $v$ first year leavers $v$ second year leavers in men (means and standard deviations)

\begin{tabular}{|c|c|c|c|}
\hline Characteristic & Stayers $(n=145)$ & $\begin{array}{l}\text { First year } \\
\text { leavers }(n=11)\end{array}$ & $\begin{array}{l}\text { Second year } \\
\text { leavers }(n=27)\end{array}$ \\
\hline $\begin{array}{l}\text { Morbidity } \\
\text { Psychiatric score } \\
\text { Alcohol consumption (g/week) }\end{array}$ & $\begin{array}{c}10 \cdot 7(10 \cdot 5) \\
347 \cdot 1(347 \cdot 7)\end{array}$ & $\begin{array}{c}20 \cdot 0(12 \cdot 8) \\
206 \cdot 5(126 \cdot 9)\end{array}$ & $\begin{array}{c}10.5(9.9) \\
444.8(593.9)\end{array}$ \\
\hline $\begin{array}{l}\text { Sickness absence: } \\
\text { Uncertified spells } \\
\text { Uncertified days } \\
\text { Certified spells } \\
\text { Certified days } \\
\text { Total spells } \\
\text { Total days }\end{array}$ & $\begin{array}{l}1 \cdot 7(1 \cdot 8) \\
2 \cdot 2(2 \cdot 5) \\
0.5(0.9) \\
3.7(9 \cdot 0) \\
2 \cdot 2(2 \cdot 4) \\
5.9(9.9)\end{array}$ & $\begin{array}{l}1.6(1.2) \\
1.8(1.4) \\
0.1(0.3) \\
0.5(1.6) \\
1.7(1.5) \\
2 \cdot 3(2.7)\end{array}$ & $\begin{array}{l}2 \cdot 0(2 \cdot 0) \\
2 \cdot 3(2 \cdot 2) \\
0.9(1 \cdot 3) \\
2 \cdot 6(3 \cdot 9) \\
2 \cdot 8(3 \cdot 1) \\
4.8(5 \cdot 6)\end{array}$ \\
\hline $\begin{array}{l}\text { Attitude to work } \\
\text { Work involvement } \\
\text { Intrinsic job motivation } \\
\text { Work motivation } \\
\text { Perceived intrinsic job characteristics } \\
\text { Job satisfaction } \\
\text { Job attachment } \\
\text { Social stresses and supports }\end{array}$ & $\begin{array}{l}29.8(4.8) \\
44.0(5 \cdot 5) \\
34.8(3.7) \\
33.2(6.6) \\
73.2(10.9) \\
1.6(6.6)\end{array}$ & $\begin{array}{r}27 \cdot 9(7 \cdot 2) \\
31.9(7 \cdot 7) \\
34.6(2 \cdot 9) \\
29.6(8 \cdot 5) \\
62.2(8 \cdot 1) \\
3.5(7 \cdot 2)\end{array}$ & $\begin{array}{l}29 \cdot 7(6 \cdot 7) \\
31 \cdot 9(4 \cdot 7) \\
33 \cdot 2(7 \cdot 3) \\
30 \cdot 6(8 \cdot 2) \\
67 \cdot 8(12 \cdot 2) \\
2 \cdot 4(10 \cdot 1)\end{array}$ \\
\hline $\begin{array}{l}\text { Housing } \\
\text { Finance } \\
\text { Occupation } \\
\text { Social life } \\
\text { Marriage } \\
\text { Family } \\
\text { Domestic responsibilities }\end{array}$ & $\begin{array}{l}2 \cdot 1(0 \cdot 8) \\
2 \cdot 5(0 \cdot 7) \\
2 \cdot 2(0 \cdot 8) \\
2 \cdot 3(0 \cdot 8) \\
2 \cdot 0(0 \cdot 8) \\
2 \cdot 0(0 \cdot 8)\end{array}$ & $\begin{array}{l}1.7(0.7) \\
2.3(0.7) \\
1.4(0.9) \\
1.9(0.7) \\
1.3(1.0) \\
1.3(1.0)\end{array}$ & $\begin{array}{l}1.8(0.6) \\
1.9(0.7) \\
1.8(0.7) \\
2.2(0.7) \\
1.9(0.8) \\
1.9(0.8)\end{array}$ \\
\hline $\begin{array}{l}\text { Responsibility } \\
\text { Activity } \\
\text { Total } \\
\text { Demographic variables }\end{array}$ & $\begin{array}{l}25 \cdot 8(9 \cdot 8) \\
50 \cdot 9(19 \cdot 2) \\
74 \cdot 9(28 \cdot 7)\end{array}$ & $\begin{array}{l}26 \cdot 6(14 \cdot 9) \\
66 \cdot 1(48 \cdot 9) \\
94 \cdot 9(61 \cdot 2)\end{array}$ & $\begin{array}{l}25 \cdot 2(9 \cdot 4) \\
48 \cdot 0(18 \cdot 2) \\
73 \cdot 2(26 \cdot 1)\end{array}$ \\
\hline $\begin{array}{l}\text { \% Married } \\
\text { No of children } \\
\text { Tenure (years) } \\
\text { Travel distance (miles) }\end{array}$ & $\begin{array}{l}42 \% \\
0 \cdot 2(0 \cdot 5) \\
4 \cdot 1(2 \cdot 4) \\
11 \cdot 4(11 \cdot 0)\end{array}$ & $\begin{array}{l}66 \cdot 7 \% \\
0 \cdot 2(0 \cdot 4) \\
4 \cdot 1(2 \cdot 1) \\
6 \cdot 3(4 \cdot 2)\end{array}$ & $\begin{array}{l}53 \% \\
0.4(0.7) \\
3.6(2.2) \\
14.4(11.4)\end{array}$ \\
\hline
\end{tabular}


FACTORS ASSOCIATED WITH TURNOVER IN THE FIRST YEAR

Tables 1 and 2 compare the characteristics of male and female executive officers, respectively, who did not leave the Home Office during the course of the study, "stayers," with those who left within 12 months of their clinical assessment, "first year leavers," and with those who left within 24 months of their clinical assessment, "second year leavers."

Compared with stayers, male first year leavers have double the severity of psychiatric morbidity at clinical assessment but a lower weekly alcohol consumption and lower annual sickness absence. In addition, they have lower scores on the scales measuring job satisfaction, job attachment, and intrinsic job motivation, and they perceive worse intrinsic job characteristics than do stayers. They also report more social stress in housing, social life, family and occupation, and more domestic activities.

The picture for women is similar in that, compared with stayers, female first year leavers have double the severity of psychiatric morbidity and lower job satisfaction and job attachment. Unlike the men, however, female first year leavers have double the weekly alcohol consumption and almost double the annual sickness absence (in terms of frequency and duration), with no particular differences in social stresses and supports, compared with stayers.

To answer the question of how far psychiatric, social, occupational, and demographic variables measured at critical assessment could predict labour turnover during the next 12 months, the following $\stackrel{0}{\rightarrow}$ variables were chosen for discriminant analysistotal psychiatric score, tenure, travel distance, marital status, sickness absence, attitudes to work, social stresses and supports, alcohol consumption, and domestic activities and responsibilities. Inclusion of all these variables resulted in the correct prediction of labour turnover for $94.8 \%$ of men $(97.6 \%$ of stayers and $55.7 \%$ of leavers) and for $94.9 \%$ of women ( $97.6 \%$ of stayers and $77.3 \%$ of leavers). A second analysis was carried out for each sex using $\varnothing$ only those variables that were responsible for a change in Rao's V significant at the 5\% level.

This enabled $94.7 \%$ of the men to be classified correctly (99.2\% of stayers and $33.3 \%$ of leavers) using the variables of occupational stress and sup- $f$ port, family stress and support, job satisfaction, 윽 travel distance, domestic activities and respon- sibilities, marital status, psychiatric score, and work involvement (table 3 ).

The second discriminant function analysis in $\frac{\omega}{\omega}$ women enabled $90.8 \%$ of women to be classified

Table 2 Comparison of the characteristics of stayers $v$ first year leavers $v$ second year leavers in women (means and standard deviations)

\begin{tabular}{|c|c|c|c|}
\hline Characteristics & Stayers $(n=96)$ & $\begin{array}{l}\text { First year } \\
\text { leavers }(n=15)\end{array}$ & $\begin{array}{l}\text { Second year } \\
\text { leavers }(n=27)\end{array}$ \\
\hline \multicolumn{4}{|l|}{ Morbidity } \\
\hline $\begin{array}{l}\text { Psychiatric score } \\
\text { Alcohol consumption (g/week) }\end{array}$ & $\begin{array}{l}11 \cdot 6(11 \cdot 4) \\
99 \cdot 4(119 \cdot 4)\end{array}$ & $\begin{array}{c}20.6(8 \cdot 1) \\
195.8(259 \cdot 7)\end{array}$ & $\begin{aligned} & 7 \cdot 7(6 \cdot 0) \\
& 223 \cdot 9(202 \cdot 0)\end{aligned}$ \\
\hline \multicolumn{4}{|l|}{ Sickness absence: } \\
\hline Uncertified spells & $1 \cdot 7(1 \cdot 5)$ & $2 \cdot 8(1.6)$ & $2.4(1.9)$ \\
\hline Uncertified days & $2 \cdot 3(2 \cdot 0)$ & $3.5(2.7)$ & $3.0(2.4)$ \\
\hline Certified spells & $0.6(1.0)$ & $1 \cdot 1(1.6)$ & $0.8(1.4)$ \\
\hline Certified days & $5 \cdot 3(20 \cdot 3)$ & $11 \cdot 1(27 \cdot 0)$ & $3 \cdot 1(4 \cdot 6)$ \\
\hline Total spells & $2 \cdot 3(2 \cdot 0)$ & $3.8(2.5)$ & $3 \cdot 2(2 \cdot 7)$ \\
\hline Total days & $7 \cdot 5(20 \cdot 3)$ & $14 \cdot 5(26 \cdot 3)$ & $6.0(5 \cdot 3)$ \\
\hline \multicolumn{4}{|l|}{ Attitude to work } \\
\hline Work involvement & $31 \cdot 8(4 \cdot 2)$ & $29 \cdot 2(5 \cdot 3)$ & $29.9(2 \cdot 7)$ \\
\hline Intrinsic job motivation & $35.4(4.4)$ & $35.7(4 \cdot 7)$ & $35.5(4.4)$ \\
\hline Work motivation & $35 \cdot 0(4 \cdot 2)$ & $33.7(5.6)$ & $33.9(4.4)$ \\
\hline Perceived intrinsic job characteristics & $31 \cdot 2(7 \cdot 2)$ & $30.4(6.7)$ & $32.8(3.7)$ \\
\hline Job satisfaction & $72.9(10 \cdot 3)$ & $69 \cdot 3(10 \cdot 4)$ & $74.6(7 \cdot 9)$ \\
\hline \multicolumn{4}{|l|}{ Social stresses and supports } \\
\hline Housing & $2.4(0.8)$ & $2 \cdot 1(0.9)$ & $2.5(0.7)$ \\
\hline Finance & $2.6(0.6)$ & $2.5(0.8)$ & $2.5(0.7)$ \\
\hline Occupation & $2 \cdot 2(0.8)$ & $1.7(0.8)$ & $1.8(0.7)$ \\
\hline Social life & $2.5(0.8)$ & $2.4(0.8)$ & $2.3(0.8)$ \\
\hline Marriage & $2.2(0.8)$ & $2.5(0.8)$ & $2.4(0.7)$ \\
\hline Family & $2 \cdot 1(0.8)$ & $2 \cdot 2(1 \cdot 0)$ & $1.9(0.8)$ \\
\hline \multicolumn{4}{|l|}{ Domestic responsibilities } \\
\hline Activity & $47 \cdot 4(22 \cdot 7)$ & $43.8(17 \cdot 6)$ & $53.9(21 \cdot 6)$ \\
\hline Total & $73 \cdot 3(34 \cdot 2)$ & $67 \cdot 2(26 \cdot 5)$ & $79.7(31.9)$ \\
\hline \multicolumn{4}{|l|}{ Demographic variables } \\
\hline$\%$ Married & $47 \cdot 2 \%$ & $75 \%$ & $38 \cdot 5 \%$ \\
\hline No of children & $0.0(0.1)$ & $0.0(0.0)$ & $0.0(0.0)$ \\
\hline Tenure & $4.9(2 \cdot 4)$ & $4.5(1.8)$ & $5.3(2.8)$ \\
\hline Travel distance (miles) & $14.0(13.8)$ & $13 \cdot 5(11 \cdot 3)$ & $9.5(6.3)$ \\
\hline
\end{tabular}


Table 3 Labour turnover in men in the first 12 months: discriminant analysis with selected variables (variables in order of insertion into the equation)

\begin{tabular}{lc}
\hline Variable & $\begin{array}{c}\text { Standardised discriminant } \\
\text { function coefficient }\end{array}$ \\
\hline Occupational stress and support & $0 \cdot 0126$ \\
Family stress and support & $0 \cdot 1429$ \\
Job satisfaction & 0.3897 \\
Travel distance & 0.5153 \\
Domestic activities & 0.9921 \\
Domestic responsibilities & 0.8036 \\
Marital status & 0.4457 \\
Psychiatric score & 0.4336 \\
Work involvement & 0.2849 \\
94.7\% of individuals correctly classified: \\
Group I (stayers) & $99.2 \%$ \\
Group II (leavers) & $33.3 \%$ \\
\hline
\end{tabular}

correctly ( $95.3 \%$ of stayers and $62.1 \%$ of leavers), using the variables of psychiatric score, marital stress and support, alcohol consumption, higher order need strength, work involvement, marital status, job attachment, and intrinsic job motivation (table 4).

Table 4 Labour turnover in women in the furst 12 months: discriminant analysis with selected variables (variables in order of insertion into the equation)

\begin{tabular}{lc}
\hline Variable & $\begin{array}{c}\text { Standardised discriminant } \\
\text { function coefficient }\end{array}$ \\
\hline Psychiatric score & 0.7435 \\
Marital stress and support & 0.7715 \\
Alcohol consumption & 0.5648 \\
Higher order need strength & -0.2233 \\
Work involvement & -0.2499 \\
Marital status & -0.4395 \\
Job attachment & -0.5785 \\
Intrinsic job motivation & 0.3878 \\
90\% of individuals correctly classified: & $95.3 \%$ \\
Group 1 (stayers) & $62.1 \%$ \\
Group 2 (leavers) & \\
\hline
\end{tabular}

\section{FACTORS ASSOCIATED WITH TURNOVER IN THE SECOND YEAR}

Further reference to table 1 shows that compared with stayers, those men who would subsequently leave the Home Office between 12 and 24 months after the assessment interview (male second year leavers) presented a similar occupational, psychiatric, and social profile at that interview, but had a higher alcohol consumption and more frequent spells of absence.

Further reference to table 2 shows that, compared with stayers, those women who would subsequently leave the Home Office between 12 and 24 months after the assessment interview (female second year leavers) had double the alcohol consumption, an increased frequency of sickness absence (although not duration), but a lower psychiatric score. They also have increased domestic responsibilities, slightly reduced job attachment, and again no particular differences in social stresses and supports.

To examine how far psychiatric, social, occupational, and demographic variables measured at initial assessment could predict labour turnover between 12 and 24 months after the assessment interview, the following variables were chosen for discriminant analysis-total psychiatric score, tenure, travel distance, marital status, sickness absence, attitudes to work, social stress and supports, alcohol consumption, and domestic activities and responsibilities. Inclusion of all these variables resulted in the correct prediction of labour turnover for $91.2 \%$ of men $(97.0 \%$ of stayers and $56.6 \%$ of leavers) and for $85.3 \%$ of women ( $92.5 \%$ of stayers and $59.6 \%$ of leavers).

A second analysis was carried out for each sex using only those variables responsible for a change in Rao's V, significant at the 5\% level.

This analysis enabled $86.4 \%$ of men to be classified correctly $(96.0 \%$ of stayers and $34.6 \%$ of leavers) (table 5). The second analysis in women enabled $82.4 \%$ of women to be classified correctly $(91.3 \%$ of stayers and $30.4 \%$ of leavers) (table 6).

Table 5 Labour turnover of men in the second 12 months: discriminant analysis with selected variables (variables in order of insertion into the equation)

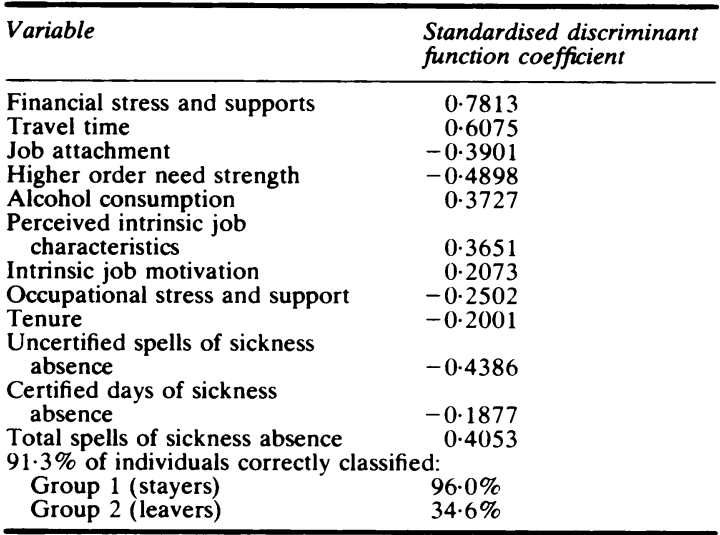

\section{Discussion}

Attempts to understand the causes of labour turnover have largely concentrated on the relation between occupational attitudes and labour turnover." Porter and Steers concluded that job satisfaction is consistently and universally related to labour turnover ${ }^{12}$ but no such relation was found by Talacchi 
Table 6 Labour turnover in women in the second 12 months: discriminant analysis with selected variables (variables in order of insertion into the equation)

\begin{tabular}{lc}
\hline Variable & $\begin{array}{c}\text { Standardised discriminant } \\
\text { function coefficient }\end{array}$ \\
\hline Alcohol consumption & 0.480 \\
Work involvement & -0.6804 \\
Domestic activity & 0.5160 \\
Psychiatric score & -0.6023 \\
Occupational stress & -0.5883 \\
Perceived intrinsic job & \\
characteristics & 0.6096 \\
Family stress and support & -0.3725 \\
Total days of sickness absence & -0.2890 \\
82.4\% of individuals correctly classified: \\
$\quad$ Group 1 (stayers) & $91.3 \%$ \\
Group 2 (leavers) & $50.4 \%$ \\
\hline
\end{tabular}

in a study of 93 industrial organisations, ${ }^{13}$ or by Katzell et $a{ }^{14}$ and Kilbridge. ${ }^{15}$ Pettman suggests that the more probable intermediate position is that, although job dissatisfaction may be a sufficient condition for high labour turnover, it is not a necessary condition. ${ }^{16}$

The relation between the health of an employee and labour turnover has only rarely been studied. ${ }^{17}$ Some suggestive evidence that neurotic workers might be more prone to change their jobs than those enjoying normal mental health was found by Cherry who retrospectively examined data from the National Survey of Health and Development and found that young men and women who had several jobs before the age of 18 had more psychiatric problems between ages 18 and 25 than more occupationally stable young workers. ${ }^{18}$ Cherry discussed several hypotheses that might account for this observation. Job changing in the early years set up a pattern of employment that puts stress on the individual and results in personal problems. Alternatively, early job changing may be caused by incipient personality or psychiatric problems that become more evident in the next seven years. Thirdly, both job changing and social behaviour may result from an inability (or unwillingness) to adopt a life style congruent with the expectations of the majority, this low level of congruence leading in turn to nervous or psychiatric troubles.

The only other prospective study to examine the contribution of psychiatric morbidity, as assessed at personal interview by a psychiatrist, to labour turnover was carried out three decades ago. ${ }^{19}$ At that time, modern epidemiological methods of screening for psychiatric disorder had not been developed, and the authors used an unstandardised, unvalidated clinical assessment, rating each worker on a five point scale for "recent mental health." They interviewed 100 female unskilled light engineering workers and 100 male unskilled medium and heavy engineering workers in the first week of their employment, and rated $43 \%$ of the men and $53 \%$ of the women neurotic.

Such prevalence rates are high, and may be partly attributable to the unstandardised clinical assessment. Six months after interview 21 men had left, 14 of whom had neurotic symptoms. When examined in more detail, however, only 12 of the 34 with rating 4 (mildly handicapped) left and 22 stayed, and only two of the nine with rating 5 (moderately handicapped) left and seven stayed. Other influences such as occupational attitudes and social stresses and supports were not measured.

The data from this study support the view that labour turnover is a complex phenomenon, and suggest that the presence of psychatric morbidity is as important as occupational attitudes in predicting labour turnover in both men and women during the 12 months after assessment.

The discriminant function analyses show the relative difficulty of identifying those individuals who will subsequently leave the organisation. The analyses were able to identify correctly only half the men and three quarters of the women who would subsequently leave the Home Office within 12 months of the assessment, and half of each sex who would subsequently leave between 12 and 24 months later.

It was expected, on a priori grounds, that predic-? tion of turnover in the second 12 months would be less good than for the first 12 months, but this was not the case for men and was only marginally so for women, although the data indicate substantial differences between first and second year leavers.

\section{Conclusions}

The data from this study support the view that minor psychiatric illness is an important cause of labour turnover, and further research is needed to assess whether early detection and treatment of minor psychiatric problems can significantly reduce labour turnover and its potential costs to the employer and employee.

I am grateful to the Civil Service Medical Advisory Service, the Home Office Establishment, the Staff Society, and the individual executive officers without whose whole hearted cooperation the study could not have been possible, and to Mrs Dorothy Faulds who typed the manuscript.

The field work for the study was carried out while I held a Wellcome Trust Fellowship. 


\section{References}

' Shepherd M, Cooper B, Brown AC, Kalton GW. Psychiatric illness in general practice. London: Oxford University Press, 1966.

${ }^{2}$ Henderson S, Byrne DG, Duncan-Jones P. Neurosis and the social environment. Sydney Australia: Academic Press, 1981.

${ }^{3}$ Fraser R. The incidence of neurosis among factory workers. (Industrial Health Research Board Report No 90.) London: HMSO 1947.

4 Jenkins R. Sex differences in minor morbidity. Psychological Medicine Monograph No 7 (in press).

${ }^{s}$ Goldberg D, Huxley P. Mental illness in the community. In: The pathway to psychiatric care. London: Tavistock Publications; 1980.

- Williams P, Clare A. Psychological disorders in general practice. London: Academic Press, 1979.

7 Goldberg D. Manual of the general health questionnaire. Windsor: National Foundation for Education Research, 1978.

${ }^{8}$ Goldberg D, Cooper B, Eastwood M, Kedward HB, Shepherd M. A standardised psychiatric interview for use in community surveys. Br J Prev Soc Med 1970;24:18-23.

' Warr P, Cook J, Wall T. Scales for the measurement of some work attitudes and aspects of psychological well being. Journal of Occupational Psychology 1979;52:129-48.

10 Jenkins R, Mann AH, Belsey E. The background, design and use of a short interview to assess social stress and support in clincial settings. Soc Sci Med 1981;15E: 193-203.

"March JG, Simon HA. Organisations. New York: John Wiley, 1958.

12 Porter LW, Steers RM. Organisational, work and personal factors in employee turnover and absenteeism. Psychol Bull 1973;80:151-76.

${ }_{13}$ Talacchi S. Organization size, industrial attitudes and behaviour: an empirical study. Administration Science Quarterly 1960;5:398-420.

14 Katzell MD, Barrett RS, Parker TC. Job satisfaction, job performance and situational characteristics. J Appl Psychol 1961;45:65-72.

is Kilbridge MD. Turnover, absence and transfer rates as indicators of employee dissatisfaction with repetitive work. Industrial and Labour Relations Review 1961;15:21-32.

“Pettman BO. Some factors influencing labour turnover: a review of research literature. Industrial Relations Journal 1973;4: 43-61.

17 Ho CJ. Health and labour turnover in a department store. Personnel Journal 1930;9:216-21.

${ }_{18}$ Cherry N. Persistent job changing-is it a problem? Journal of Occupational Psychology 1976;49:203-21.

${ }^{14}$ Markowe M, Barber LED. Mental health in relation to the labour turnover of unskilled workers in a large industrial establishment. Br J Prev Soc Med 1953;7:205-10. 